\title{
Addition of Purified Tannin Sources and Polyethylene Glycol Treatment on Methane Emission and Rumen Fermentation in Vitro
}

\author{
A. Jayanegara ${ }^{\mathrm{a}, \mathrm{b}, *}$, H. P. S. Makkara, ${ }^{\mathrm{a},}$ \& K. Becker ${ }^{\mathrm{a}}$ \\ anstitute for Animal Production in the Tropics and Subtropics (480b), University of Hohenheim \\ 70593 Stuttgart, Germany \\ ${ }^{b}$ Department of Nutrition and Feed Technology, Faculty of Animal Science, Bogor Agricultural University \\ Jalan Agatis, Kampus IPB Darmaga, Bogor 16680, Indonesia \\ cAnimal Production and Health Division, Food and Agriculture Organization of the United Nations \\ Rome, Italy \\ (Received 31-12-2014; Reviewed 28-01-2015; Accepted 06-03-2015)
}

\begin{abstract}
The objectives of this experiment were (1) to observe the effects of purified tannins and polyethylene glycol (PEG) on in vitro rumen fermentation and methanogenesis, and (2) to assess the accuracy of volatile fatty acid (VFA) profiles in predicting methane emission. Hydrolysable and condensed tannins were extracted and purified from chestnut, sumach, mimosa and quebracho. Hay and concentrate mixture $(70: 30 \mathrm{w} / \mathrm{w}, 380 \mathrm{mg})$ was incubated in Hohenheim glass syringe containing $10 \mathrm{~mL}$ rumen liquor $+20 \mathrm{~mL}$ buffer. The purified tannins were injected into the syringes at a concentration of $1.0 \mathrm{mg} / \mathrm{mL}$ each, either without or with PEG 6,000 addition in three replicates. Results revealed that a decrease of methane emission $(20 \%-27 \%)$ was observed when the purified tannins were added into basal diet as compared to control $(\mathrm{P}<0.05)$, and PEG addition increased methane emission $(\mathrm{P}<0.05)$. All purified tannins decreased total gas and total VFA production $(P<0.05)$. The $\mathrm{H}_{2}$ recovery of the treatments ranged from $86.7 \%$ to $95.3 \%$. Estimation of methane emission by using VFA profiles revealed an accurate result with a very low root mean square prediction error $(1.75 \%)$. It is concluded that tannins mitigate methane emission while PEG neutralize such effect, and VFA profiles are accurate predictors of the emission.
\end{abstract}

Key words: tannin, polyethylene glycol, methane, rumen, stoichiometry

\section{ABSTRAK}

Penelitian ini bertujuan (1) untuk mengevaluasi pengaruh tanin murni dan polietilen glikol (PEG) terhadap fermentasi rumen dan metanogenesis secara in vitro, dan (2) untuk menganalisis akurasi profil volatile fatty acid (VFA) dalam memprediksi emisi metana. Tanin terhidrolisis dan terkondensasi diekstrak dan dimurnikan dari chestnut, sumach, mimosa dan quebracho. Rumput hay dan konsentrat $(70: 30 \mathrm{w} / \mathrm{w}, 380 \mathrm{mg})$ diinkubasi di dalam syringe Hohenheim bersama dengan $10 \mathrm{ml}$ cairan rumen $+20 \mathrm{ml}$ larutan buffer. Tanin dimasukkan ke dalam syringe pada konsentrasi $1,0 \mathrm{mg} / \mathrm{ml}$ dengan atau tanpa penambahan PEG dalam tiga ulangan. Hasil menunjukkan bahwa terjadi penurunan emisi metana $(20 \%-27 \%)$ ketika tanin murni ditambahkan ke dalam ransum basal dibandingkan dengan kontrol $(\mathbf{P}<0,05)$, dan penambahan PEG meningkatkan emisi gas metana $(\mathrm{P}<0,05)$. Semua tanin murni menurunkan produksi gas total dan VFA total $(\mathrm{P}<0,05)$. Recovery $\mathrm{H}_{2}$ berkisar $86,7 \%-95,3 \%$. Estimasi emisi metana secara stoikiometri dari profil VFA menunjukkan hasil yang akurat dengan nilai root mean square prediction error yang sangat rendah $(1,75 \%)$. Disimpulkan bahwa tanin dapat menekan emisi metana sementara PEG menetralkan efek tersebut, dan profil VFA merupakan prediktor yang akurat terhadap emisi metana.

Kata kunci: tanin, polietilen glikol, metana, rumen, stoikiometri

${ }^{*}$ Corresponding author:

E-mail: anuragaja@apps.ipb.ac.id 


\section{INTRODUCTION}

Ruminants have the ability to convert roughages such as grasses and agricultural by-products into high quality foods for human such as milk and meat. This is possible due to the action of microbes residing in the rumen in degrading such fibrous materials into their monomers which are later on being utilized for various anabolic reactions. However, ruminants also produce methane $\left(\mathrm{CH}_{4}\right)$, another main greenhouse gas (GHG) that contributes to global warming after carbon dioxide $\left(\mathrm{CO}_{2}\right)$ (Monteny et al., 2006). The presence of methanogenic archaea within rumen microflora enables formation of methane from $\mathrm{CO}_{2}$ and $\mathrm{H}_{2}$ or methanogenesis to occur (Morgavi et al., 2010). Such methane emission from enteric fermentation, apart from its association with environmental problem, is also representing a certain amount of energy loss from the animals (Cottle et al., 2011). It is therefore essential to develop various feeding strategies that simultaneously mitigate methane emission and increase the efficiency of energy utilization.

Among a number of nutritional attempts for mitigating enteric methane emission, plant secondary compounds such as tannins, saponins and essential oils are considered as the promising substances due to their abundant in nature (Benchaar \& Greathead, 2011; Jayanegara et al., 2010; Jayanegara et al., 2012). With regard to tannins, previous studies have reported that tannin-containing plants or tannin extracts decreased methane emissions both in in vitro and in vivo experiments (Animut et al., 2008; Jayanegara et al., 2009a; Jayanegara et al., 2012). Some purified tannins had also been tested regarding their efficacy in mitigating methane, but the magnitude of methane decrease was low due to the low concentration applied, i.e. $0.5 \mathrm{mg} / \mathrm{mL}$ (Jayanegara et al., 2009b). In the present experiment, the concentrations of purified tannins from chestnut (Castanea sp.), sumach (Rhus typhina), mimosa (Mimosa tenuiflora) and quebracho (Schinopsis balansae) were doubled than that of Jayanegara et al. (2009b); the first two sources were hydrolysable tannins and the others were condensed tannins. Further, polyethylene glycol (PEG), a tannin binding agent, was added in conjunction with the purified tannins to observe whether such addition would influence methane emission or not.

On the other hand, measurement of methane emission from ruminants in vivo requires relatively sophisticated and expensive equipment. Therefore in vitro methods have been developed to measure the gas emission. Standard method for such measurement is by using infrared methane analyser (Jayanegara et al., 2009a, 2009c) or gas chromatograph (Jayanegara et al., 2011). Unfortunately, there are limited animal nutrition laboratories that have such devices in Indonesia. Indirect estimation was attempted in the country to quantify methane emission such as by using $\mathrm{CO}_{2}$ entrapment technique (Yogianto et al., 2014; Yuliana et al., 2014) or by employing a stoichiometric equation from volatile fatty acid (VFA) profiles (Jayanegara et al., 2013). Regarding the latter approach, root mean square prediction error (RMSPE) of estimated methane value from VFA against value obtained from direct measurement was still high, indicating that there was a substantial bias in the methane values between the two methods (Jayanegara et al., 2013). Therefore, as a second objective, this study was aimed at confirming whether VFA profiles could accurately predict actual methane emission or not.

\section{MATERIALS AND METHODS}

\section{Tannin Extraction and Purification from Plant Materials}

Plant materials of chestnut and sumach (leaves of the plants) were obtained from University of Hohenheim botanical garden, Stuttgart, Germany, whereas plant materials of mimosa and quebracho (barks of the plants) were obtained from Mongolia (Jayanegara et al., 2009a). Extraction of tannins was performed in an ultrasonic water bath at $135 \mathrm{~W}$ (Branson 3210, Connecticut, USA) by following the procedure of Makkar (2003). An amount of $1 \mathrm{~g}$ of each tannin source was mixed with $50 \mathrm{~mL}$ of $50 \%$ aqueous methanol and put in the water bath for $25 \mathrm{~min}$ at room temperature. The extraction was done twice of each sample, both supernatants were pooled and centrifuged at $10,000 \mathrm{~g}$ for $10 \mathrm{~min}$ at $4{ }^{\circ} \mathrm{C}$.

After the tannins were extracted, they were purified by using a Sephadex LH-20 column as outlined by Makkar \& Becker (1994). Briefly, supernatant obtained from the extraction procedure was added with $0.1 \%$ of ascorbic acid to avoid tannin oxidation. The supernatant was passed through swollen slurry of Sephadex LH-20 prepared in $50 \%$ aqueous methanol and washed five times with the respective solvent. Non-tannins were removed out through this procedure. The remaining tannins were then eluted using $70 \%$ aqueous acetone. Acetone was removed under vacuum at about $30^{\circ} \mathrm{C}$ and subsequently the aqueous solution containing tannins was lyophilized. The tannins were further used in the following in vitro rumen fermentation experiment.

\section{In Vitro Incubation}

An amount of $380 \mathrm{mg}$ hay and concentrate mixture (70:30 w/w) was incubated in $100 \mathrm{~mL}$ Hohenheim glass syringe containing $10 \mathrm{~mL}$ rumen liquor $+20 \mathrm{~mL}$ buffer following the procedure of Makkar et al. (1995). The hay and concentrate used were similar to those used in Jayanegara et al. (2009b). Rumen fluid (including solid material) was collected before morning feeding from two non-lactating dairy cows fed on roughage and concentrate based diets. The rumen fluid was mixed, strained and filtered by passing through a $100 \mu \mathrm{m}$ nylon net. The lyophilized tannins were solubilized in distilled water (30 mg tannins/mL distilled water) and subsequently an amount of $1 \mathrm{~mL}$ tannin solutions were injected into the syringes to make up the tannin concentration of $1.0 \mathrm{mg} /$ $\mathrm{mL}$ fermentation fluid. Additionally, polyethylene glycol (PEG) with the molecular weight of $6,000 \mathrm{kDa}$, a tannin binding agent (Jayanegara \& Sofyan, 2008), was added in the amount of $750 \mathrm{mg}$ in each syringe that contained $30 \mathrm{~mL}$ of fermentation fluid. The following treatments were tested:

T1 : Control 
$\mathrm{T} 2: \mathrm{T} 1+$ chestnut tannins

T3 : T1 + chestnut tannins + PEG

$\mathrm{T} 4: \mathrm{T} 1+$ sumach tannins

T5 : T1 + sumach tannins + PEG

T6 : $\mathrm{T} 1+$ mimosa tannins

$\mathrm{T} 7: \mathrm{T} 1+$ mimosa tannins + PEG

T8 : T1 + quebracho tannins

T9 : T1 + quebracho tannins + PEG

Allocation of treatments into experimental units was based on a completely randomized design in which each syringe represented as the experimental unit. In vitro incubation was carried out at $39^{\circ} \mathrm{C}$ for $24 \mathrm{~h}$. Variables measured after $24 \mathrm{~h}$ incubation were total gas production, methane emission, protozoal number and volatile fatty acid (VFA) profile, i.e. acetate $\left(\mathrm{C}_{2}\right)$, propionate $\left(\mathrm{C}_{3}\right)$, butyrate $\left(\mathrm{C}_{4}\right)$, isobutyrate $\left(\right.$ iso $\left.\mathrm{C}_{4}\right)$, valerate $\left(\mathrm{C}_{5}\right)$ and isovalerate $\left(i s o \mathrm{C}_{5}\right)$. Total VFA was obtained by summing up the all individual VFA concentrations. This experiment was performed in three replicates, represented by one Hohenheim glass syringe per replicate.

\section{Variable Measurements}

Total gas production was recorded from the scale on the syringe after $24 \mathrm{~h}$ of incubation. Methane emission was measured by using an infrared methane analyzer (Pronova Analysentechnik GmbH \& Co. KG, Berlin, Germany) as previously conducted by (Jayanegara et al., 2009a). Apart from being directly measured, methane emission was also estimated stoichiometrically from VFA profile by following Moss et al. (2000) equation:

$$
\mathrm{CH}_{4}=0.45 \mathrm{C}_{2}-0.275 \mathrm{C}_{3}+0.40 \mathrm{C}_{4}(\mathrm{mmol})
$$

Hydrogen recovery was calculated from the ratio between hydrogen utilized and hydrogen produced as follow:

$$
\begin{aligned}
& \mathrm{H}_{2} \text { produced }=2 \mathrm{C}_{2}+\mathrm{C}_{3}+4 \mathrm{C}_{4}(\mathrm{mmol}) \\
& \mathrm{H}_{2} \text { utilized }=4 \mathrm{CH}_{4}+2 \mathrm{C}_{3}+2 \mathrm{C}_{4}(\mathrm{mmol}) \\
& \mathrm{H}_{2} \text { recovery }=\mathrm{H}_{2} \text { utilized } / \mathrm{H}_{2} \text { produced } \times 100 \%
\end{aligned}
$$

Since the amount of methane emission is influenced by hydrogen recovery (Jayanegara et al., 2013), adjustment was made by considering a hydrogen recovery of 90\% (Moss et al., 2000).

For analysis of VFA profile, $1 \mathrm{~mL}$ of fermentation fluid was aliquoted into $1.5 \mathrm{~mL}$ Eppendorf cup and immediately kept on ice to stop the fermentation process. The sample was subsequently centrifuged at 30,000 g, 10 min and $4{ }^{\circ} \mathrm{C}$. After centrifugation, supernatant and pellet were carefully separated. An amount of $630 \mu \mathrm{L}$ of the supernatant was transferred into a fresh vial and $70 \mu \mathrm{L}$ of internal standard, i.e. methylvaleric acid was added. All samples were kept at $4{ }^{\circ} \mathrm{C}$ over night to precipitate soluble proteins and then were centrifuged (30,000 g, $10 \mathrm{~min}, 4{ }^{\circ} \mathrm{C}$ ) to remove the precipitate. Samples were finally injected into a gas chromatograph device (GC 14A, Shimadzu Corp., Kyoto, Japan) with a stainless steel column packed with 10\% SP ${ }^{\mathrm{TM}}-1000,1 \% \mathrm{H}_{3} \mathrm{PO}_{4^{\prime}}$ Chromosorb WAW (Suppelco Inc., Bellafonte, PA, USA). Individual VFA peaks were detected by the chromatograph and the peak area was converted into concentration (in $\mathrm{mmol} / \mathrm{L}$ ).
A uniform aliquot of the syringe contents after $24 \mathrm{~h}$ of incubation was used for microscopic counts of protozoa. An equal volume (500 $\mu \mathrm{L}$ each) of the aliquot was mixed with the fixative containing bromocresol green $(0.06 \mathrm{~g} / 100 \mathrm{~mL})$, sodium chloride $(0.8 \mathrm{~g} / 100 \mathrm{~mL})$ and $1: 10$ diluted formalin in water. The counting was performed on Neubauer counting chamber (Paul Marienfield GmbH \& Co. KG, Lauda-Königshofen, Germany) with counting depth $0.1 \mathrm{~mm}$ and counting area $1 \mathrm{~mm}^{2}$.

\section{Data Analysis}

Data were analyzed by using one-way analysis of variance (ANOVA) with the following statistical model:

$$
Y_{i j}=\mu+\tau_{i}+\varepsilon_{i j}
$$

where $Y_{i j}$ is the observed value for the $j^{\text {th }}$ replicate of the $i^{\text {th }}$ treatment, $\mu$ is the overall mean, $\tau_{i}$ is the treatment effect for the $i^{\text {th }}$ treatment (fixed effect), and $\varepsilon_{i j}$ is the random residual error (Kaps \& Lamberson, 2004). The differences among treatments were compared by using Duncan's multiple range test when the ANOVA result of each variable showed significant different at $\mathrm{P}<0.05$.

Total gas production and methane emission data with PEG addition were divided by their corresponding data without PEG addition and multiplied by $100 \%$ as previously conducted by Jayanegara \& Sofyan (2008) and Jayanegara et al. (2009a), respectively. Such data indicated the potency of each purified tannins in decreasing rumen fermentation and mitigating methane emission, respectively.

Methane emission estimated from VFA profile was plotted against its observed value. For an ideal model, the estimated methane emission is equal to the observed methane. Assessment of prediction error was made through mean square prediction error (MSPE) according to Kebreab et al. (2008):

$$
\operatorname{MSPE}=\sum_{i=1}^{n} \frac{\left(\mathrm{O}_{i}-\mathrm{P}_{i}\right)^{2}}{n}
$$

where $\mathrm{n}=$ number of run, $\mathrm{O}=$ the observed methane emission and $\mathrm{P}_{\mathrm{i}}=$ the predicted or estimated methane emission. Root MSPE (RMSPE) was used as a measure of prediction accuracy. The RMSPE value was expressed as a proportion (percentage) from the observed methane emission. Further, a linear regression analysis was performed between the estimated and the observed methane.

\section{RESULTS AND DISCUSSION}

Addition of all purified tannins at $1 \mathrm{mg} / \mathrm{mL}$ decreased total gas production as compared to control $(\mathrm{P}<0.05$; Table 1). The magnitude of gas decrease was higher for condensed tannins than those of hydrolysable tannins $(\mathrm{P}<0.05)$. When PEG was added, total gas production increased to almost similar to control; this was true for all purified tannins and the range of increase was between $10 \%-20 \%$ (Figure 1). The decrease of gas production due to tannins is possible through interaction between tannins and feed components such as protein 
Table 1. Gas production, methane emission and protozoa population of purified tannin additions without or with polyethylene glycol (PEG)

\begin{tabular}{llllc}
\hline \multicolumn{1}{c}{ Treatment } & $\begin{array}{c}\text { Gas } \\
(\mathrm{mL})\end{array}$ & $\begin{array}{c}\mathrm{CH} 4 \\
(\mathrm{~mL})\end{array}$ & $\begin{array}{c}\mathrm{CH} 4 \\
(\mathrm{mmol})\end{array}$ & $\begin{array}{c}\text { Protozoa } \\
(\log \text { count } / \mathrm{mL})\end{array}$ \\
\hline Control & $95.8^{\mathrm{e}}$ & $19.4^{\mathrm{d}}$ & $0.76^{\mathrm{d}}$ & 5.13 \\
Chestnut & & & & \\
$\quad$ No PEG & $79.3^{\mathrm{b}}$ & $14.9^{\mathrm{b}}$ & $0.58^{\mathrm{b}}$ & 4.99 \\
$\quad$ With PEG & $91.3^{\mathrm{de}}$ & $18.5^{\mathrm{c}}$ & $0.72^{\mathrm{c}}$ & 5.04 \\
Sumach & & & & \\
$\quad$ No PEG & $83.8^{\mathrm{c}}$ & $15.4^{\mathrm{b}}$ & $0.60^{\mathrm{b}}$ & 5.07 \\
$\quad$ With PEG & $92.5^{\mathrm{de}}$ & $18.5^{\mathrm{c}}$ & $0.72^{\mathrm{c}}$ & 5.19 \\
Mimosa & & & & \\
$\quad$ No PEG & $77.0^{\mathrm{ab}}$ & $14.9^{\mathrm{b}}$ & $0.58^{\mathrm{b}}$ & 5.13 \\
$\quad$ With PEG & $91.7^{\mathrm{de}}$ & $18.4^{\mathrm{c}}$ & $0.72^{\mathrm{c}}$ & 5.08 \\
Quebracho & & & & \\
No PEG & $74.0^{\mathrm{a}}$ & $14.2^{\mathrm{a}}$ & $0.56^{\mathrm{a}}$ & 5.13 \\
$\quad$ With PEG & $89.0^{\mathrm{d}}$ & $18.2^{\mathrm{c}}$ & $0.71^{\mathrm{c}}$ & 5.04 \\
SEM & 1.52 & 0.38 & 0.015 & 0.015 \\
P-value & $<0.001$ & $<0.001$ & $<0.001$ & 0.061 \\
\hline
\end{tabular}

Note: Means in the same column with different superscripts differ at $\mathrm{P}<0.05$.

and carbohydrate (both structural and non-structural carbohydrate) (Jayanegara et al., 2012). The main interaction between tannins and those macromolecules is via hydrogen bond (Mueller-Harvey, 2006). Such bind prevents degradation and fermentation of the molecules partially to form gas and thus lowers its production. Since the bind is stronger for condensed tannins and there is a partial degradation of hydrolysable tannins by certain rumen microbial species particularly at the sugar attachment sites (Mueller-Harvey, 2006), it is unsurprising that the gas decrease was higher on addition of the condensed tannins than the other ones. Addition of PEG neutralizes the effect of tannins since the PEG has higher affinity to tannins compared to the macromolecules (Makkar et al., 1995). The increase of gas production due to neutralization effect of PEG on tannins (present in green tea and black tea by-products) was also observed by Kondo et al. (2014).

A decrease of methane emission was observed when the purified tannins were added into basal diet as compared to control $(\mathrm{P}<0.05)$; the range of decrease was between $20.6 \%$ and $26.8 \%$ and between $21.1 \%$ and $26.3 \%$ when expressed in $\mathrm{mL}$ and $\mathrm{mmol}$, respectively. The magnitude of decrease due to tannins in the present study was higher than the previous study of Jayanegara et al. (2009b) that ranged between $13.3 \%$ and $13.9 \%$. Apparently this was due to the lower concentration of tannins used in that study, i.e. only half $(0.5 \mathrm{mg} / \mathrm{mL})$ of the concentration used in the present experiment. No clear distinction between condensed and hydrolysable tannins was observed with regard to methane emission. With regard to the mechanisms in which tannins are able to mitigate ruminal methane emissions, two mechanisms have been proposed by Tavendale et al. (2005), i.e.

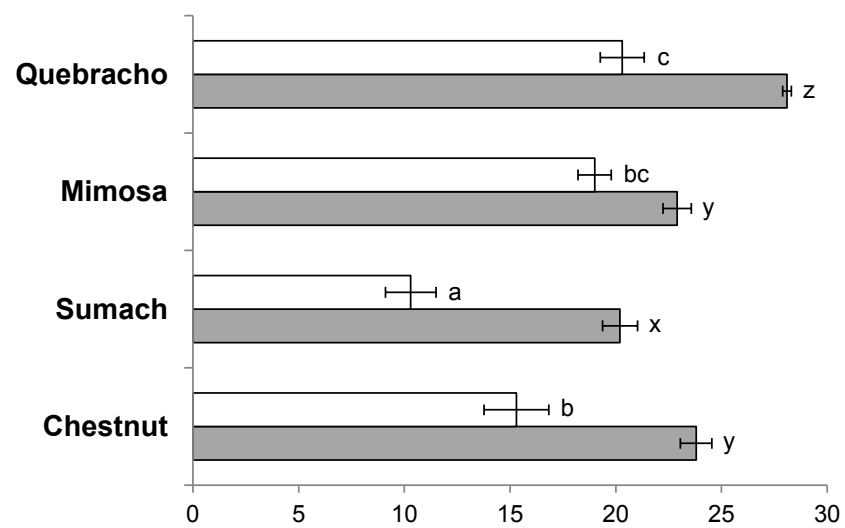

Figure 1. Percent gas ( $\square$ ) and methane ( $\square$ ) increase of various purified tannin sources due to polyethylene glycol addition. a,b,c Significantly different between purified tannin sources for percent gas increase; $x, y, z$ Significantly different between purified tannin sources for percent methane increase.

(1) indirectly, through reduction in fibre digestion which in turn decreases $\mathrm{H}_{2}$ production as a precursor of methane, and (2) directly, through inhibition of the growth or activity of methanogens. It seems that both mechanisms are reflected in the present study through simultaneous depression in total gas production and methane emission due to tannin additions. Furthermore, tannins are known to decrease protozoa population (Bhatta et al., 2009) in which part of the methanogens are living together (Morgavi et al., 2010) and contribute to the lower methane emission. However, the reduced population of protozoa was not proven in the present experiment. This was supported by a meta-analysis study conducted by Jayanegara et al. (2012); across all studies, increasing levels of tannins did not significantly reduce log protozoa population in both in vitro and in vivo experiments.

Similar to the pattern of total gas production, methane emission increased after PEG addition (Figure 1). The increase of methane emission due to PEG ranged from approximately $20 \%$ to $27 \%$. Such increase of methane was also observed in our previous study (Jayanegara et al., 2009a) in which the PEG was added into a number of tannin-containing plants obtained from Mongolia and Germany. This response confirms the effect of tannins in mitigating ruminal methane emission since PEG has a specific affinity to tannins over other compounds (Makkar et al., 1995; Kondo et al., 2014). The PEG binds tannins, making the plant secondary compounds lost their biological activities in interacting with other macromolecules such as protein and carbohydrate as well as lost their anti-microbial properties such as fibre-degrading bacteria and methanogens. It has to be noted that PEG has various molecular weight (e.g., 1,000, 4,000, 6,000 and 20,000) and its interaction with tannins may vary according to the respective weight. Other polymers that have similar properties like PEG in deactivating tannin biological activity are polyvinyl pyrrolidone (PVP) and polyvinyl polypyrrolidone (PVPP) (Kondo et al., 2014). 
The pattern of total VFA production was similar to that of total gas; addition of all purified tannins significantly reduced total VFA $(\mathrm{P}<0.05)$ and PEG addition increased back the variable although could not completely recover the concentration similar to control (Table 2). This was also true for all individual VFA, i.e. acetate $\left(\mathrm{C}_{2}\right)$, propionate $\left(\mathrm{C}_{3}\right)$, butyrate $\left(\mathrm{C}_{4}\right)$, isobutyrate $\left(\right.$ iso $\left.\mathrm{C}_{4}\right)$, valerate $\left(\mathrm{C}_{5}\right)$ and isovalerate $\left(\right.$ iso $\left.\mathrm{C}_{5}\right)$. Such VFA is a major energy source for ruminants (Jayanegara et al., 2006). The mechanism whereby tannins decreased total and individual VFA is similar as explained above since VFA is also an end product of rumen microbial fermentation (Jayanegara et al., 2006). Purified tannins decreased acetate to propionate ratio significantly $(\mathrm{P}<0.05)$. An inhibition on the growth of cellulolytic bacteria in the presence of tannins is apparently a causal factor of such VFA shift (Jayanegara et al., 2012) thus lowers the acetate production as a major VFA resulted from cellulolytic bacteria fermentation. Although propionate in general was decreased due to purified tannin additions, the magnitude of decrease was relatively small as compared to acetate decrease. The decrease of acetate to propionate ratio due to purified tannin additions is favourable towards mitigation of methanogenesis since fermentation of glucose to acetate yields $\mathrm{H}_{2}$, a main substrate of the methane formation, and on the contrary, the fermentation of glucose to propionate consumes $\mathrm{H}_{2}$ (Morgavi et al., 2010; Hristov et al., 2013). It has to be noted that butyrate concentrations in all treatments were rather high as compared to that of the typical one in the rumen. Since this was consistently observed across all treatments, therefore it was unlikely due to the treatment effects. Apparently the high population of butyrate-producing bacteria in the inoculum is a plausible explanation of such pattern, which may be as a result of high-fibre intake of the donor cows or the presence of resistance starch in the concentrate diet (Li et al., 2012).
Less $\mathrm{H}_{2}$ was produced on the addition of purified hydrolysable and condensed tannins as compared to control $(\mathrm{P}<0.05$; Table 3$)$. Depression of substrate degradation due to tannins is apparently a plausible explanation. Addition of PEG improved the $\mathrm{H}_{2}$ production but still hardly similar to control. Metabolic hydrogen is produced during degradation and fermentation of feed polymers (mainly carbohydrates, both structural and non-structural carbohydrates) through EmdenMeyerhof-Parnas pathway, which is an oxidative process under anaerobic condition in the rumen (Moss et al.,

Table 3. Hydrogen $\left(\mathrm{H}_{2}\right)$ balance of purified tannin additions without or with polyethylene glycol (PEG)

\begin{tabular}{lccc}
\hline \multicolumn{1}{c}{ Treatment } & $\begin{array}{c}\mathrm{H}_{2} \text { produced } \\
(\mathrm{mmol})\end{array}$ & $\begin{array}{c}\mathrm{H}_{2} \text { utilized } \\
(\mathrm{mmol})\end{array}$ & $\begin{array}{c}\mathrm{H}_{2} \text { recovery } \\
(\%)\end{array}$ \\
\hline Control & $4.79^{\mathrm{d}}$ & $4.47^{\mathrm{d}}$ & $93.2^{\mathrm{c}}$ \\
Chestnut & & & \\
$\quad$ No PEG & $4.01^{\mathrm{a}}$ & $3.60^{\mathrm{a}}$ & $90.3^{\mathrm{b}}$ \\
$\quad$ With PEG & $4.51^{\mathrm{c}}$ & $4.21^{\mathrm{c}}$ & $93.3^{\mathrm{c}}$ \\
Sumach & & & \\
No PEG & $4.30^{\mathrm{b}}$ & $3.75^{\mathrm{b}}$ & $87.2^{\mathrm{a}}$ \\
$\quad$ With PEG & $4.70^{\mathrm{d}}$ & $4.25^{\mathrm{c}}$ & $90.6^{\mathrm{b}}$ \\
Mimosa & & & \\
No PEG & $4.06^{\mathrm{a}}$ & $3.62^{\mathrm{a}}$ & $89.0^{\mathrm{b}}$ \\
With PEG & $4.38^{\mathrm{bc}}$ & $4.18^{\mathrm{c}}$ & $95.3^{\mathrm{d}}$ \\
Quebracho & & & $86.7^{\mathrm{a}}$ \\
No PEG & $4.05^{\mathrm{a}}$ & $3.51^{\mathrm{a}}$ & $93.0^{\mathrm{c}}$ \\
With PEG & $4.51^{\mathrm{c}}$ & $4.19^{\mathrm{c}}$ & 0.59 \\
SEM & 0.054 & 0.067 & $<0.001$ \\
P-value & $<0.001$ & $<0.001$ & \\
\hline
\end{tabular}

Note: Means in the same column with different superscripts differ at $\mathrm{P}<0.05$.

Table 2. Volatile fatty acid (VFA) profile (in mmol/L) of purified tannin additions without or with polyethylene glycol (PEG)

\begin{tabular}{|c|c|c|c|c|c|c|c|c|}
\hline Treatment & Total VFA & $\mathrm{C}_{2}$ & $\mathrm{C}_{3}$ & $\mathrm{C}_{4}$ & isoC $_{4}$ & $\mathrm{C}_{5}$ & isoC $_{5}$ & $\mathrm{C}_{2} / \mathrm{C}_{3}$ \\
\hline Control & $77.8^{\mathrm{d}}$ & $50.6^{\mathrm{e}}$ & $12.5^{\mathrm{b}}$ & $11.5^{\mathrm{d}}$ & $0.86^{\mathrm{e}}$ & $0.99^{\mathrm{f}}$ & $1.28^{\mathrm{d}}$ & $4.04^{\mathrm{b}}$ \\
\hline \multicolumn{9}{|l|}{ Chestnut } \\
\hline No PEG & $65.6^{\mathrm{a}}$ & $42.1^{\mathrm{a}}$ & $11.8^{\mathrm{a}}$ & $9.4^{\mathrm{a}}$ & $0.65^{\mathrm{a}}$ & $0.72^{\mathrm{a}}$ & $0.91^{\mathrm{a}}$ & $3.57^{\mathrm{a}}$ \\
\hline With PEG & $73.3^{c}$ & $48.5^{\mathrm{d}}$ & $11.7^{\mathrm{a}}$ & $10.4^{\mathrm{bc}}$ & $0.72^{\mathrm{bc}}$ & $0.84^{c}$ & $1.06^{\mathrm{b}}$ & $4.13^{\mathrm{b}}$ \\
\hline \multicolumn{9}{|l|}{ Sumach } \\
\hline No PEG & $70.2^{\mathrm{b}}$ & $45.2^{\mathrm{b}}$ & $12.4^{\mathrm{b}}$ & $10.2^{\mathrm{b}}$ & $0.68^{\mathrm{ab}}$ & $0.81^{\mathrm{b}}$ & $1.00^{\mathrm{b}}$ & $3.65^{a}$ \\
\hline With PEG & $75.9^{\mathrm{d}}$ & $50.2^{\mathrm{e}}$ & $11.7^{\mathrm{a}}$ & $11.1^{\mathrm{d}}$ & $0.77^{\mathrm{d}}$ & $0.95^{\mathrm{e}}$ & $1.16^{\mathrm{c}}$ & $4.28^{c}$ \\
\hline \multicolumn{9}{|l|}{ Mimosa } \\
\hline No PEG & $66.3^{\mathrm{a}}$ & $42.6^{a}$ & $11.8^{\mathrm{a}}$ & $9.6^{\mathrm{a}}$ & $0.65^{\mathrm{a}}$ & $0.72^{\mathrm{a}}$ & $0.90^{\mathrm{a}}$ & $3.61^{\mathrm{a}}$ \\
\hline With PEG & $71.2^{\mathrm{bc}}$ & $46.7^{c}$ & $11.5^{\mathrm{a}}$ & $10.3^{\mathrm{bc}}$ & $0.74^{\text {cd }}$ & $0.89^{d}$ & $1.12^{c}$ & $4.05^{\mathrm{b}}$ \\
\hline \multicolumn{9}{|l|}{ Quebracho } \\
\hline No PEG & $66.0^{\mathrm{a}}$ & $42.2^{\mathrm{a}}$ & $11.8^{\mathrm{a}}$ & $9.7^{\mathrm{a}}$ & $0.65^{\mathrm{a}}$ & $0.71^{\mathrm{a}}$ & $0.94^{\mathrm{a}}$ & $3.59^{\mathrm{a}}$ \\
\hline With PEG & $73.2^{\mathrm{c}}$ & $47.9^{\mathrm{cd}}$ & $11.7^{\mathrm{a}}$ & $10.7^{\mathrm{c}}$ & $0.76^{\mathrm{cd}}$ & $0.93^{e}$ & $1.17^{c}$ & $4.08^{\mathrm{b}}$ \\
\hline SEM & 0.84 & 0.63 & 0.07 & 0.13 & 0.014 & 0.02 & 0.025 & 0.052 \\
\hline P-value & $<0.001$ & $<0.001$ & 0.003 & $<0.001$ & $<0.001$ & $<0.001$ & $<0.001$ & $<0.001$ \\
\hline
\end{tabular}

Note: Means in the same column with different superscripts differ at $\mathrm{P}<0.05$. 
2000). The pattern of $\mathrm{H}_{2}$ utilization among the treatments was identical to that of $\mathrm{H}_{2}$ production and ranged from 3.51 to $4.47 \mathrm{mmol}$. Utilization of $\mathrm{H}_{2}$ is possible since a number of rumen microbes such as $\mathrm{H}_{2}$-utilizing bacteria and methanogens are capable of consuming $\mathrm{H}_{2}$ (Morgavi et al., 2010). Further, the $\mathrm{H}_{2}$ is also used during VFA synthesis or incorporated into microbial organic matter (Moss et al., 2000). The $\mathrm{H}_{2}$ recovery of the treatments ranged from $86.7 \%$ to $95.3 \%$. Such range is within the normal range of $\mathrm{H}_{2}$ recovery, i.e. between $78 \%$ and $96 \%$ (Moss et al., 2000) or an average of $90 \%$ (Castro Montoya et al., 2011).

Estimation of methane emission by using VFA profiles revealed an accurate result with a high coefficient of determination and a very low RMSPE, i.e. 1.75\% (Figure 2). This indicates that stoichiometric estimation of methane from VFA is very useful when there is a lack of equipment to directly measure the gas. It has to be noted that all individual VFA values are requested to be converted into mmol since stoichiometric relationship is based on mol, not other units of measurements. The result was different with that of reported by Jayanegara et al. (2013) in which the stoichiometric equation overestimated the actual methane emission. An explanation was that the $\mathrm{H}_{2}$ recovery obtained in that study was much lower compared to the present study, i.e. between $28.9 \%$ to $56.2 \%$. Although adjustment by considering $\mathrm{H}_{2}$ recovery improved the accuracy and lowered the RMSPE to $8.01 \%$ (Jayanegara et al., 2013), the current study was much more accurate by providing lower RMSPE. Nevertheless, in any case, the consideration of $\mathrm{H}_{2}$ recovery is essential to obtain a more accurate methane emission. In a circumstance that the RMSPE is still high, such stoichiometric prediction is useful in making an order or rank which feed produces lower or higher ruminal methane emission in vitro.

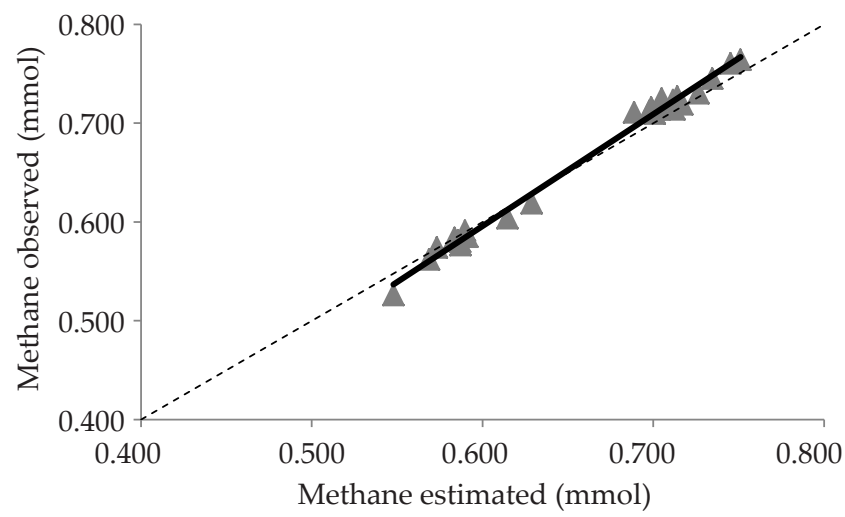

Figure 2. Plot between estimated (from volatile fatty acid profile) and observed (using infrared methane analyzer) methane emission. Regression equation: Methane observed $=-0.084+1.133 \times$ Methane estimated $(\mathrm{P}<0.001$; $\mathrm{R}^{2}=0.992 ; \mathrm{RMSPE}=1.75 \%$ ). Dashed line indicates an ideal line where the estimated methane emission is equal to the observed methane emission.

\section{CONCLUSION}

Addition of purified hydrolysable and condensed tannins at $1 \mathrm{mg} / \mathrm{ml}$ into basal diet decreased methane emission by $20 \%-27 \%$ from control. No clear distinction was observed between the hydrolysable and the condensed tannins tested with regard to methane emission. Simultaneous addition of PEG with the tannins increased methane, confirming a specific effect of tannins in mitigating methane emission. Estimation of methane emission by using VFA profiles revealed an accurate result with a high coefficient of determination and a very low RMSPE, indicating the usefulness of such stoichiometric relationship when there is a lack of equipment.

\section{ACKNOWLEDGEMENT}

The first author is grateful to DAAD (Deutscher Akademischer Austauschdienst) for providing a scholarship to pursue postgraduate study at University of Hohenheim, Germany. All authors are also thankful to Mr. Herrmann Baumgärtner and Mrs. Beatrix Fischer for excellent technical help during the experimental period.

\section{REFERENCES}

Animut, G., R. Puchala, A. L. Goetsch, A. K. Patra, T. Sahlu, V. H. Varel, \& J. Wells. 2008. Methane emission by goats consuming diets with different levels of condensed tannins from lespedeza. Anim. Feed Sci. Technol. 144:212-227. http://dx.doi.org/10.1016/j.anifeedsci.2007.10.014

Benchaar, C. \& H. Greathead. 2011. Essential oils and opportunities to mitigate enteric methane emissions from ruminants. Anim. Feed Sci. Technnol. 166-167:338-355. http:// dx.doi.org/10.1016/j.anifeedsci.2011.04.024

Bhatta, R., Y. Uyeno, K. Tajima, A. Takenaka, Y. Yabumoto, I. Nonaka, O. Enishi, \& M. Kurihara. 2009. Difference in the nature of tannins on in vitro ruminal methane and volatile fatty acid production and on methanogenic archaea and protozoal populations. J. Dairy Sci. 92:5512-5522. http:// dx.doi.org/10.3168/jds.2008-1441

Castro Montoya, J., A. M. Bhagwat, N. Peiren, S. De Campeneere, D. De Baets \& V. Fievez. 2011. Relationships between odd- and branched-chain fatty acid profiles in milk and calculated enteric methane proportion for lactating dairy cattle. Anim. Feed Sci. Technol. 166-167:596-602. http://dx.doi.org/10.1016/j.anifeedsci.2011.04.080

Cottle, D. J., J. V. Nolan, \& S. G. Wiedemann. 2011. Ruminant enteric methane mitigation: a review. Anim. Prod. Sci. 51:491-514. http://dx.doi.org/10.1071/AN10163

Hristov, A. N., J. Oh, J. L. Firkins, J. Dijkstra, E. Kebreab, G. Waghorn, H. P. S. Makkar, A. T. Adesogan, W. Yang, C. Lee, \& P. J. Gerber. 2013. Mitigation of methane and nitrous oxide emissions from animal operations: I. A review of enteric methane mitigation options. J. Anim. Sci. 91:5045-5069. http://dx.doi.org/10.2527/jas.2013-6583

Jayanegara, A., A. S. Tjakradidjaja, \& T. Sutardi. 2006. Fermentabilitas dan kecernaan in vitro ransum limbah agroindustri yang disuplementasi kromium anorganik dan organik. Med. Pet. 29:54-62.

Jayanegara, A., \& A. Sofyan. 2008. Penentuan aktivitas biologis tanin secara in vitro menggunakan Hohenheim gas test dengan polietilen glikol sebagai determinan. Med. Pet. 31:44-52.

Jayanegara, A., N. Togtokhbayar, H. P. S. Makkar, \& K. Becker. 2009a. Tannins determined by various methods as 
predictors of methane production reduction potential of plants by an in vitro rumen fermentation system. Anim. Feed Sci. Technol. 150:230-237. http://dx.doi.org/10.1016/ j.anifeedsci.2008.10.011

Jayanegara, A., H. P. S. Makkar, \& K. Becker. 2009b. Emisi metana dan fermentasi rumen in vitro ransum hay yang mengandung tanin murni pada konsentrasi rendah. Med. Pet. 32:184-194.

Jayanegara, A., A. Sofyan, H. P. S. Makkar, \& K. Becker. 2009c. Kinetika produksi gas, kecernaan bahan organik and produksi gas metana in vitro pada hay dan jerami yang disuplementasi hijauan mengandung tanin. Med. Pet. 32:120-129.

Jayanegara, A., G. Goel, H. P. S. Makkar, \& K. Becker. 2010. Reduction in methane emissions from ruminants by plant secondary metabolites: effects of polyphenols and saponins. In: Odongo, N. E., M. Garcia, \& G. J. Viljoen (Eds). Sustainable Improvement of Animal Production and Health. Food and Agriculture Organization of the United Nations (FAO), Rome, Italy, pp. 151-157.

Jayanegara, A., F. Leiber, \& M. Kreuzer. 2012. Meta-analysis of the relationship between dietary tannin level and methane formation in ruminants from in vivo and in vitro experiments. J. Anim. Physiol. Anim. Nutr. 96:365-375. http:// dx.doi.org/10.1111/j.1439-0396.2011.01172.x

Jayanegara, A., Ikhsan, \& T. Toharmat. 2013. Assessment of methane estimation from volatile fatty acid stoichiometry in the rumen in vitro. J. Indonesian Trop. Anim. Agric. 38:103-108.

Jayanegara, A., E. Wina, \& J. Takahashi. 2014. Meta-analysis on methane mitigating properties of saponin-rich sources in the rumen in vitro: influence of addition levels and plant sources. Asian Australas. J. Anim. Sci. 27:1426-1435. http:// dx.doi.org/10.5713/ajas.2014.14086

Kaps, M., \& W. R. Lamberson. 2004. Biostatistics for Animal Science. CABI Publishing, Oxfordshire, UK.

Kebreab, E., K. A. Johnson, S. L. Archibeque, D. Pape \& T. Wirth. 2008. Model for estimating enteric methane emissions from United States dairy and feedlot cattle. J. Anim. Sci. 86:2738-2748. http://dx.doi.org/10.2527/jas.2008-0960

Kondo, M., Y. Hirano, N. Ikai, K. Kita, A. Jayanegara, \& H. Yokota. 2014. Assessment of anti-nutritive activity of tannins in tea by-products based on in vitro ruminal fermentation. Asian Australas. J. Anim. Sci. 27:1571-1576. http://dx.doi. org/10.5713/ajas.2014.14204

Li, R. W., S. Wu, R. L. Baldwin VI, W. Li \& C. Li. 2012. Perturbation dynamics of the rumen microbiota in response to exogenous butyrate. Plos One 7:e29392. http://dx.doi. org/10.1371/journal.pone.0029392
Makkar, H. P. S., \& K. Becker. 1994. Isolation of tannins from leaves of some trees and shrubs and their properties. J. Agric. Food Chem. 42:731-734. http://dx.doi.org/10.1021/ jf00039a026

Makkar, H. P. S., M. Blümmel, \& K. Becker. 1995. Formation of complexes between polyvinyl pyrrolidones or polyethylene glycols and tannins, and their implication in gas production and true digestibility in in vitro techniques. Brit. J. Nutr. 73:897-913. http://dx.doi.org/10.1079/BJN19950095

Makkar, H. P. S. 2003. Quantification of Tannins in Tree and Shrub Foliage, A Laboratory Manual. Kluwer Academic Publishers, Dordrecht, The Netherlands. http://dx.doi. org/10.1007/978-94-017-0273-7

Monteny, G. J., A. Bannink, \& D. Chadwick. 2006. Greenhouse gas abatement strategies for animal husbandry. Agric. Ecosyst. Environ. 112:163-170. http://dx.doi.org/10.1016/ j.agee.2005.08.015

Morgavi, D. P., E. Forano, C. Martin, \& C. J. Newbold. 2010. Microbial ecosystem and methanogenesis in ruminants. Animal 4:1024-1036. http://dx.doi.org/10.1017/ S1751731110000546

Moss, A. R., J. P. Jouany, \& J. Newbold. 2000. Methane production by ruminants: its contribution to global warming. Ann. Zootech. 49:231-253. http://dx.doi.org/10.1051/animres:2000119

Mueller-Harvey, I. 2006. Unravelling the conundrum of tannins in animal nutrition and health. J. Sci. Food Agric. 86:20102037. http://dx.doi.org/10.1002/jsfa.2577

Tavendale, M. H., L. P. Meagher, D. Pacheco, N. Walker, G. T. Attwood, \& S. Sivakumaran. 2005. Methane production from in vitro rumen incubations with Lotus pedunculatus and Medicago sativa, and effects of extractable condensed tannin fractions on methanogenesis. Anim. Feed Sci. Technol. 123-124:403-419. http://dx.doi.org/10.1016/ j.anifeedsci.2005.04.037

Yogianto, A. Sudarman, E. Wina, \& A. Jayanegara. 2014. Supplementation effects of tannin and saponin extracts to diets with different forage to concentrate ratio on in vitro rumen fermentation and methanogenesis. J. Indonesian Trop. Anim. Agric. (in press).

Yuliana, P., E. B. Laconi, E. Wina, \& A. Jayanegara. 2014. Extraction of tannins and saponins from plant sources and their effects on in vitro methanogenesis and rumen fermentation. J. Indonesian Trop. Anim. Agric. (in press). 